\title{
THE APPLICATION OF ELECTRONIC MONITORING SYSTEMS IN ROMANIA: HOW AND IN WHAT WAYS DOES ELECTRONIC SURVEILLANCE FACILITATE A CONVICTED PERSON'S REINTEGRATION INTO SOCIETY?
}

DOI: $10.47743 /$ rdc-2018-1-0003

Vladimir-Adrian COSTEA ${ }^{1}$

\section{Abstract}

This article identifies how electronic monitoring is defined and used in relation to the idea of reintegrating the convicted person into society. In the Romanian context, the perspective using electronic monitoring has not yet generated debates and evaluations at the academic or policy-maker levels.

The originality of this research lays in the elaboration of a project for the implementation of an electronic monitoring system in the Romanian criminal justice system in relation to the "good practice models" identified in the European context. We assign a central role to the economic, social and political consequences which (re)define the legal framework of the execution of custodial sentences.

The research presents the measures and strategies that the Ministry of Justice should follow in order to implement its 2018-2024 Calendar for dealing with overcrowding and detention conditions.

Keywords: electronic monitoring; detention; overcrowding; reintegration; strategies

\section{INTRODUCTION}

In order to better understand the evolution of alternative sanctions, in this paper we shall focus on the application and use of electronic monitoring in Romania and Europe.

The main objective of this research is to analyze the - gradual or sudden - changes which have occurred as a result of the implementation of electronic monitoring systems relative to the occupancy levels of penitentiaries. Starting from a "good practices"

\footnotetext{
$1 \mathrm{PhD}$ candidate at the Doctoral School of the Faculty of Political Science of the University of Bucharest (FSPUB), supervised by Prof. Georgeta GHEBREA, PhD.
} 
model identified in the European system, we propose the establishment of a framework for the optimal implementation of electronic monitoring in the Romanian case.

The secondary objective of this research lies in the evaluation of measures and strategies proposed by the Ministry of Justice in the 2018-2024 Calendar for dealing with overcrowding and detention conditions. We propose to evaluate the allotment of new convict accommodations in contrast to prisons' occupancy levels.

We justify the choice of subject as a result of the position and role which criminal policy plays in the institutional, territorial and functional framework of the rule of law, taking into account the provisions of Law 254/2013 on the execution of sentences and detention measures ordered by judicial bodies during criminal proceedings.

Another argument which justifies our choice is the complexity of alternative forms of sanction which produce a high level of societal echo. The application of electronic monitoring solutions induces strong disruptions in society when the remotely monitored person cannot reintegrate into society.

The originality of this research is the elaboration of a design for the implementation of electronic monitoring in Romania in relation to the "good practice models" identified in European context. A central role of this is attributed to the economic, social and political consequences of (re)defining the framework for the execution of custodial sentences. In this research we present the measures and strategies which the Ministry of Justice should follow in order to implement its 2018-2024 Calendar for dealing with overcrowding and detention conditions.

The main argument captures the definition and use of alternative forms of punishment - by establishing the framework for the use of electronic monitoring by the courts - in relation to the degree of a convicted persons' reintegration into society. The objective of maintaining the link with the support environment prevails in contrast to the punitive dimension, which is why the adaptation of the legal framework is based on the assessment of the social, economic and political consequences. The use of social surveys and the gradual application of electronic monitoring (by testing remote surveillance by pilot courts), contribute to maintaining a low level of recidivism among beneficiaries.

At the same time, the measures and strategies for individualizing alternative forms of punishment are implemented in the context of wide-ranging debates in the academic environment, focusing primarily on the rights and responsibilities of the convicted person. Researchers' debates and evaluations aim to address the limits of the use of electronic monitoring, in order to emphasize that the (in)efficiency of this measure is determined by its design and implementation phases.

In the Romanian context, the perspective of using electronic monitoring has not yet generated debates and evaluations at the level of researchers and policy makers. In the absence of debates and evaluations, sudden changes to the institutional design of criminal policies produces short-term changes which may remedy the problems present in the Romanian prison system with regard to detention conditions and overcrowding dynamics. 


\section{The application of electronic monitoring systems in Romania...}

In order to have an overview of the issues we are analyzing, we shall consider the contribution in the Romanian context of the founders of the sociology of deviance, Sorin M. Rădulescu and Dan Banciu. Despite the efforts of the two researchers to place society at the center of "labeling" approaches to the acts of individuals as delinquent, this perspective has not been internalized by society. For this reason, the regulation of criminal policies has been made in relation to sanctioning the authors of anti-social acts, which is why penitentiaries have performed mainly punitive functions.

This research is placed in the perspective proposed by the neo-institutional analysis $^{2}$ of democratic governance and democratization ${ }^{3}$, distancing itself, however, from transitologic studies centered exclusively on the construction of the political regime, providing a secondary status to governance process ${ }^{4}$. The option for neo-institutional analysis lies in the definition of institutional change in relation to the changes to the social environment.

Our research is based on a corpus of sources composed of normative acts, reports by the National Penitentiary Administration, the European Court of Human Rights (ECHR), the European Committee for the Prevention of Torture and Inhuman or Degrading Treatment (CPT), and data received from the National Penitentiary Administration and from the Ministry of Foreign Affairs.

\section{ELECTRONIC MONITORING: CONCEPT AND REGULATION}

"In the age of electronics it is not surprising that some have hoped that Electronic Monitoring (EM) would be a technological magic bullet solving difficult problems with little effort or Curfew Orders with electronic monitoring (COs). To those who have seen other new promising innovations, it comes as no surprise that there is no magic bullet" 5 .

The concept of electronic monitoring cannot be reduced to a simple tracking and monitoring function of convicted persons outside of detention facilities ${ }^{6}$. The extension

\footnotetext{
2 See P.A. Hall, Rosemary C.R. Taylor, Political Science and the Three New Institutionalisms, in Political Studies, Vol. 44, Nr. 5, December 1996, pp. 936-957; M. Bevir, Democratic Governance, Princeton N.J., Princeton University Press, 2010.

3 See S. Skowronek, Building a New American State: The Expansion of National Administrative Capacities, 1877-1920, Cambridge: Cambridge University Press, 1982; S. Steinmo, K. Thelen, F. Longstreth (eds.), Structuring Politics: Historical Institutionalism in Comparative Analysis, Cambridge: Cambridge University Press, 1992; M. Shefter, Political Parties and the State, Princeton N.J., Princeton University Press, 1994; J.J. Linz, A. Stepan, Problems of Democratic Transition and Consolidation, Baltimore, Johns Hopkins University Press, 1996; J.-M. Eymeri-Douzans, J. Pierre (eds.), Administrative Reforms and Democratic Governance, London, Routledge, 2011.

${ }^{4}$ See Th.J. Lowi, Arenas of Power, introduction by N.K. Nicholson, Boulder CO, Paradigm Publishers, 2009.

${ }^{5}$ I. Brownlee, Community Punishment: A critical introduction, Longman, London, 1998, p. 122, apud J. Ardley, The theory, development and application of Electronic Monitoring in Britain, Internet Journal of Criminology, 2005, pp. 1-86.

${ }^{6}$ A. Jandrić Nišević, N. Franić and S. Rajić, An overview of the research into the effectiveness of electronic monitoring as an alternative sanction, Criminology \& Social Integration Journal, Vol. 23, Nr. 1, 2015, pp. 51-71.
}

STUDIES AND ARTICLES 
to the conceptual and practical levels of electronic monitoring has occurred in relation to the dynamics of the political, economic, ideological and technological context within each state ${ }^{7}$. The deepening economic crisis $^{8}$, together with the downsizing of budgets allocated to overcrowded penitentiaries ${ }^{9}$, occurring at the same time as the development of new remote communication and control technologies ${ }^{10}$, have generated an "elective affinity"11 with regard to the integration of electronic monitoring technology in the mechanism of institutionalized social control ${ }^{12}$. With regard to these new challenges, researcher lan Brownlee underlines that electronic monitoring has been mistakenly perceived, in the beginning, as some sort of "technological magic bullet" able to sum up with a low effort the complex dimension of detention conditions and overcrowding.

Initially, in the model developed by Schwitzgebel, rehabilitation was pursued through bidirectional communication between therapist and subject ${ }^{13}$. Economic, material and ideological interests have transformed the serving of one's sentence outside of penitentiary into a "punitive observation and automatic control device"14. The ideological change of emphasis from rehabilitation to control has characterized the dynamics of neo-conservative policies of the '70s, which have led to the replacement of the criminal justice systems' primary objective of rehabilitation with that of isolating and controlling convicted persons ${ }^{15}$.

\footnotetext{
${ }^{7}$ S. Mainprize, Elective Affinities in the Engineering of Social Control: The Evolution of Electronic Monitoring, Electronic Journal of Sociology, 1996, pp. 1-27.

${ }^{8}$ See L.E. Flynn, House arrest: Florida's alternative eases crowding and tight budgets, Corrections Today, Vol. 64, Nr. 8, July 1986; Thomas G. Blomberg, Gordon P. Waldo and Lisa C. Burcroff, Home Confinement and Electronic Surveillance, in B.R. McCarthy (ed.), Intermediate Punishments: Intensive Supervision, Home Confinement and Electronic Surveillance, New York, Criminal Justice Press, Vol. 2, 1987, pp. 169-79; A.T. Scull, Decarceration: Community Treatment and the Deviant $-A$ Radical View, $2^{\text {nd }}$ Edition, New Brunswick, Rutgers University Press, 1984.

${ }^{9}$ See T.G. Blomberg, G.P. Waldo and L.C. Burcroff, Home Confinement and Electronic Surveillance in Belinda R. McCarthy (ed.), Intermediate Punishments: Intensive Supervision, Home Confinement and Electronic Surveillance, New York, Criminal Justice Press, Vol. 2, 1987, pp. 169-79; Charles M. Friel and Joseph B. Vaughn, A Consumer's Guide to the Electronic Monitoring of Probationers, Federal Probation, Nr. 50, 1986, pp. 3-14.

${ }^{10}$ See B.L. Ingraham and G.W. Smith, Controlling Human Behavior with Electronics, The Futurist. Aprilie 1970, pp. 60-62; B.L. Ingraham and G.W. Smith, Electronic Surveillance and Control of Behavior, Criminology, Nr. 7, 1972, pp. 35-53; R.K. Schwitzgebel, Electronic Innovation in Behavioral Sciences: A Call to Responsibility, American Psychologist, Nr. 22, 1967, pp. 364-70; R.K. Schwitzgebel, Electronic Alternatives to Imprisonment, Lex et Scientia, Nr. 5, 1968, pp. 99-104; R.K. Schwitzgebel, Behavioral Electronics Could Empty the World's Prisons, The Futurist, April 1970, pp. 59-60.

${ }^{11}$ See M. Weber, The Protestant Ethic and the Spirit of Capitalism, London, Allen and Unwin, p. 1930.

${ }^{12}$ S. Mainprize, Elective Affinities in the Engineering of Social Control: The Evolution of Electronic Monitoring, p. 4.

${ }^{13}$ R.K. Schwitzgebel, Behavioral Electronics Could Empty the World's Prisons, The Futurist, April 1970, pp. 59-60, apud S. Mainprize, Elective Affinities in the Engineering of Social Control: The Evolution of Electronic Monitoring, pp. 5-7.

${ }^{14}$ S. Mainprize, Elective Affinities in the Engineering of Social Control: The Evolution of Electronic Monitoring, pp. 9-10.

${ }^{15}$ Ibidem, pp. 5-7.
} 


\section{The application of electronic monitoring systems in Romania...}

Presently, the definitions of electronic monitoring ${ }^{16}$ vary from the emphasis placed on the (intense) surveillance function within the community ${ }^{17}$, to the application of an alternative sanction to the execution of one's sentence in prison via home arrest ${ }^{18}$. The literature relates to the application of electronic monitoring based on certain broad eligibility and rejection criteria, on the basis of which convinced persons who benefit from this measure are selected ${ }^{19}$.

On the one hand, eligibility criteria refer to: persons convicted for minor offenses; their responsibilities in taking care of children and other family members; the need for medical treatment; the victims' consent to the release of the convicted person into the community; the existence of a reasonable guarantee of the safety of members of the community ${ }^{20}$.

On the other hand, exclusion criteria include: committing a serious crime (murder, rape, assault, drug trafficking); the inadequate behavior of the convicted person throughout detention; the situations in which the convicted person will live with the victim (especially in cases of domestic violence, abuse or neglect of children); mental health issues which prevent the convicted person from having full control over their behavior; the refusal of the victim for the release of the convicted person ${ }^{21}$.

In order to properly identify the beneficiaries of remote surveillance measures through electronic monitoring, Kristal Beyens and Marjike Roosen, researches at the Department of Criminal Studies at the University of Brussels, consider it appropriate for social workers to make an initial visit to the home of the convicted persons' family members. ${ }^{22}$ On the basis of the findings of the social survey, the two researches consider it appropriate to individually select people for remote monitoring based on the availability of family members to support the convicted person ${ }^{23}$. Visits and social surveys were used in Belgium until 2006 and were later reintroduced from 2008 to 2012, but have been eliminated due to their costs and their lengthening of the proceedings ${ }^{24}$.

Even if the rules for the application of electronic monitoring vary according to the country in which it is used, the predominant perspective in national case-law is to apply electronic monitoring according to the purpose of the surveillance and the individual

\footnotetext{
${ }^{16}$ A. Jandrić Nišević et al., An overview of the research into the effectiveness of electronic monitoring as an alternative sanction, p. 52.

${ }^{17}$ See A.H. Crowe, L. Sydney, Pat Bancroft, Beverly Lawrence, Offender Supervision With Electronic Technology: A User's Guide, American Probation and Parole Association, Council of State Governments, Kentucky, 2002.

${ }^{18}$ See J. Ardley, The Theory, Development and Application of Electronic Monitoring in Britain, Internet Journal of Criminology, 2005.

${ }^{19}$ A.H. Crowe et al, Offender Supervision With Electronic Technology, 2002, apud A. Jandrić Nišević et al., An overview of the research into the effectiveness of electronic monitoring as an alternative sanction, p. 54.

${ }^{20}$ Ibidem.

${ }^{21}$ Ibidem.

${ }^{22} \mathrm{~K}$. Beyens and M. Roosen, Electronic monitoring in Belgium: a penological analysis of current and future orientations, European Journal of Probation University of Bucharest, Vol. 5, Nr. 3, 2013, pp 56-70.

${ }^{23}$ K. Beyens and M. Roosen, op. cit., p. 58.

${ }^{24}$ Ibidem.
} 
evaluation of the beneficiaries who would execute their sentence outside of detention centers. ${ }^{25}$ Nonetheless, the development of surveillance technologies have extended the potential use of electronic monitoring systems, including in the case of persons convicted for serious crimes (murder, domestic violence, sexual assault, rape etc.) ${ }^{26}$.

In view of these issues, Anita Jandrić Nišević, Nena Franić and Saša Rajić approach electronic monitoring from an ethical perspective. According to them, the main advantages of applying electronic monitoring measures are the possibilities of reducing the level of occupancy in penitentiaries as well as of allocating lower budgets for the daily upkeep of convicted persons ${ }^{27}$. Maintaining a link with the support environment (family, friends etc.), together with the possibility of employing convicted persons contributes to the reduction of the negative effects of incarceration, as well as to the latter's rehabilitation and societal reintegration ${ }^{28}$. Conversely, the authors underline that "wearing the device may cause psychological pressure" 29 , identifying, at the same time, four major dilemmas regarding the surveillance of convicted persons executing their sentence outside of prison:

1) Ensuring confidentiality $\rightarrow$ Excess electronic surveillance can disrupt the private life of a convicted person and his family, thereby violating fundamental human rights. For this reason, the consent of family members to the measure of electronic surveillance (and the specific rules of remote monitoring) is needed, in the case where they live in the same place as the convicted person ${ }^{30}$.

2) Extending social control $\rightarrow$ The application of electronic monitoring must not lead to a more severe sanction in relation to the punishment imposed by the courts for the offenses committed ${ }^{31}$.

3) The perception of public opinion regarding the maintaining of community safety $\rightarrow$ Mass media and the political elite have an important role in the shaping of public opinion regarding the prospects of reintegrating convicted persons into society. A lack of information regarding electronic monitoring, coupled with the "labels" 32 attributed to convicted persons leads to the emergence of confusion, anxiety and fear in the community as well as to a decline in their trust of state institutions ${ }^{33}$.

\footnotetext{
${ }^{25}$ A.H. Crowe et al., Offender Supervision With Electronic Technology, p. 55.

${ }^{26}$ Ibidem.

27 Ibidem, p. 59.

${ }^{28}$ Ibidem.

${ }^{29}$ Ibidem.

${ }^{30}$ Ibidem, pp. 59-60.

${ }^{31}$ Ibidem.

${ }^{32}$ H.S. Becker, E. Lemert, K. Erikson, E. Goffman and T. Scheff established the "labeling" theory in 1990 in order to answer the "age-old determinist question - «what makes one a deviant?»". The novelty of this paradigm is that the individual is deviant because he was labeled by society "with a status of «licensed outsider»", just as patients are confirmed as sick only after they get a "verdict" from doctors. See S.M. Rădulescu and D. Banciu, Sociologia crimei și criminalității, București, Casa de editură și presă "Şansa” - S.R.L., 1996, pp. 50-51.

${ }^{33}$ A. Jandrić Nišević ș.a., An overview of the research into the effectiveness of electronic monitoring as an alternative sanction, pp. 60-61.
}

CONSTITUTIONAL LAW REVIEW 


\section{The application of electronic monitoring systems in Romania...}

4) The financial and social expenditure of electronic monitoring $\rightarrow$ An important objective of using alternative sanctions is reducing the costs of upkeep for convicted persons. The costs of remote monitoring are, generally, much lower compared to the costs of incarceration, especially in situations in which penitentiaries are dealing with a high level of overcrowding, leading, therefore, to the need of building new prisons in order to ensure proper detention conditions as well as supplementing the budget for the training and remuneration of new prison staff ${ }^{34}$. Nonetheless, it is difficult to estimate the actual impact on cost reductions, which are influenced both by the duration and frequency of the use of electronic monitoring, the cost of surveillance and staffing, as well as the costs of equipment and electronic monitoring support, as well as "unpredictable costs which may appear in certain circumstances, which cannot be predicted with any certainty" (the abuse of electronic monitoring, the extension of social control, the victim's treatment, psychological trauma, personal injury) ${ }^{35}$.

On the other hand, the supporters of the theory of specific discouragement ${ }^{36}$ position themselves against the use of electronic monitoring ${ }^{37}$. In their view, in order to not void of meaning the significance of punishing offenses, alternative measures for the execution of sentences must not omit the goal of discouraging convicted persons from relapsing. In order illustrate the complexity of relapse, the theory of specific discouragement bases itself on the costs of committing a new offense, reason for which imprisonment contributes to the rehabilitation of convicted persons. Unlike this approach, recent empirical studies have shown that traditional prisons are veritable "schools of crime" where "inmates learn from each other" 38 . Starting from this argument, the adepts of the theory of social learning ${ }^{39}$ have illustrated the fact that

\footnotetext{
${ }^{34}$ A. Jandrić Nišević ş.a., An overview of the research into the effectiveness of electronic monitoring as an alternative sanction, pp. 61-62.

35 Ibidem, pp. 62-63.

${ }^{36}$ See B. Bales, K. Mann, G. Gaes, K. Barrick, T.G. Blomberg, K. Dhungana and B. McManus, Quantitative and qualitative assessment of electronic monitoring, Washington DC, U.S. Department of Justice, Office of Justice Programs, National Institute of Justice, 2010; R. Kirkland Gable and R.S. Gable, Electronic monitoring: Positive intervention strategies, Federal Probation, Vol. 69, Nr. 2, 2005, pp. 21-25; A. Hucklesby, Understanding offenders' compliance: A case study of electronically monitored curfew orders, Journal of Law \& Society, Vol. 36, Nr. 2, 2009, pp. 248-271.

${ }^{37}$ A Henneguelle, B. Monnery și A. Kensey, Better at Home than in Prison?, The Effects of Electronic Monitoring on Recidivism in France, GATE Lyon Saint-Étienne, September 2016, pp. 1-51.

${ }^{38}$ See P. Bayer, R. Hjalmarsson and D. Pozen, Building criminal capital behind bars: Peer effects in juvenile corrections, The Quarterly Journal of Economics, Vol. 124, Nr. 1, 2009, pp. 105-147; A.P. Damm and C. Gorinas, Deal drugs once, deal drugs twice: peer effects on recidivism from prisons, in C. Gorinas (Ed.), Essays on Marginalization and Integration of Immigrants and Young Criminals - A Labor Economics Perspective, Aarhus University, 2013; A. Ouss, Prison as a school of crime: Evidence from cell-level interactions, Working paper, 2011; A. Aizer and J.J. Doyle, Juvenile incarceration, human capital, and future crime: Evidence from randomly assigned judges, The Quarterly Journal of Economics, Vol. 130, Nr. 2, 2015, pp. 759-803; M. Mueller-Smith, The criminal and labor market impacts of incarceration, Working paper, 2014; B. Western, J.R. Kling și D.F. Weiman, The labor market consequences of incarceration, Crime and Delinquency, Vol. 47, Nr. 3, 2001, pp. 410-427.

${ }^{39}$ See W.D. Burrell and R.S. Gable, From B.F. Skinner to Martha Stewart: The Past, Present and Future of Electronic Monitoring of Offenders, Journal of Offender Rehabilitation, Vol. 46, Nr. 3/4, 2008, pp. 101-118; T. Brezina and A.R. Piquero, Exploring the relationship between social and non-social reinforcement in the context of social learning theory, în R.L. Akers and G.F. Jensen (eds.), Social Learning Theory and the Explanation of Crime: A Guide for the New Century, Vol. 11, New Brunswich, NJ, Transaction, 2003.
}

STUDIES AND ARTICLES 
electronic monitoring leads to a lower rate of repeat offense, as well as alleviating the stigma associated with convicted persons ${ }^{40}$.

Entourage and criminal networks in penitentiaries hinder "social rehabilitation and reintegration into the labor market of inmates due to the low degree of access to education, the exhaustion of human capital, social exclusion and the stigma which one bears even after release" ${ }^{\prime 1}$.

This approach is nuanced by Bert Useem and Anne Morrison Piehl, according to whom prison is the "ultimate intrusion of the state in citizens' lives" ${ }^{42}$, the space in which the state regulates the movement and activities of inmates. Continuing the sociological approaches developed by Michel Foucault, David Garland, Loacc Wacuant, William Chambliss, Jerome Skolnick and James Q. Whitman, penitentiary is defined by Bert Useem and Anne Morrison Piehl as the result of the effort of societal domination and exploitation. Invoking official purposes regarding retribution and control of crime are seen by Useem and Piehl as alibis for justifying aggression ${ }^{43}$. This point of view was nuanced by David Garland, according to whom the way in which penitentiaries are built illustrates the dimension of anxieties in the culture of modern society, which is marked by the uncertain and risky nature of social and economic relations ${ }^{44}$.

Isolating convicted persons is illustrated by French intellectual Loïc Wacquant, who has identified a direct correlation between the degree of penitentiary overcrowding and the level of social domination and exploitation. According to him, in penitentiaries, the high degree of occupancy leads to a heightened level of social domination and exploitation by prison staff. Exercising pressure for a long period of time leads to the isolation of inmates from the outside world, reason for which the penitentiary environment becomes excessively ghettoized ${ }^{45}$. The symbiosis between ghetto and prison culture contributes, according to Wacquant, to legitimizing political actors to apply policies for the construction of new spaces for the exertion of control ${ }^{46}$.

In order to avoid the transformation of penitentiaries into "dormitories", Jim Murdoch, professor of public law at the University of Glasgow, considers that criminal policies must be implemented with the focus on the person who has committed an offense and for which it must serve a sentence for a certain amount of time. According

\footnotetext{
${ }^{40}$ R. Di Tella and E. Schargrodsky, Criminal Recidivism after Prison and Electronic Monitoring, Buenos Aires, $6^{\text {th }}$ July 2008, pp. 1-27.

${ }^{41}$ A. Henneguelle et al., Better at Home than in Prison?, pp. 4-5.

42 B. Useem and A. Morrison Piehl, Prison State. The Clallenge of Mass Incarceration, Cambridge, New York, Melbourne, Madrid, Cape Town, Singapore, São Paulo, Cambridge University Press, 2008, p. 3.

43 Ibidem, p. 4.

${ }_{4}^{4}$ D. Garland, The Culture of Control: Crime and Social Order in Contemporary Society, Chicago, The University of Chicago Press, 2000, p. 194, apud B. Useem şi A. Morrison Piehl, Prison State. The Challenge of Mass Incarceration, p. 15.

${ }^{45}$ L. Wacquant, Deadly Symbiosis: When Ghetto and Prison Meet and Mesh, Punishment and Society, Nr. 3, 2001, p. 97, apud B. Useem and A. Morrison Piehl, Prison State. The Clallenge of Mass Incarceration, pp. 42-44.

46 Ibidem.
} 


\section{The application of electronic monitoring systems in Romania...}

to Murdoch, regardless of the offense committed, persons cannot lose their human dignity, considered "inherent and inviolable" ${ }^{47}$. The loss of freedom does not cancel the concept of "human rights", inmates must therefore be treated according to their "physical, social and legal situation"48, a reason for which Murdoch considers that decisions regarding freedom must first take into account the possibility of reconciliation and reintegration of those people into society ${ }^{49}$.

The application of intermediate sentences to people who pose a "low risk" for society contributes both to the reduction of occupancy levels in prisons as well as to the reintegration into society of people guilty of "minor" offenses, without generating rejection reactions ${ }^{50}$.

The UN Office on Drugs and Crime notes that the most appropriate tool for the real-time monitoring of a person's location is radio frequency control through GPS-equipped bracelets ${ }^{51}$. Even if technology has made significant progress over the past few decades, the challenges of using surveillance tools have not been completely addressed, reason for which electronic surveillance bracelets are not ideal instruments for surveillance, being dependent on the quality of the GPS signal ${ }^{52}$. Also, the public humiliation and stigmatization of the monitored persons, together with the discriminatory selection of beneficiaries ${ }^{53}$, as well as the promotion of extended state control represent further criticism to the use of electronic bracelets.

At the same time, the UN Office on Drugs and Crime points to two further aspects which should be taken note of by competent authorities: On the one hand, the risk of monitoring devices failing may enable convicted persons to evade surveillance. On the other hand, using remote surveillance does not automatically determine a decline in penitentiary occupancy levels, due to the risks of encouraging criminal activity if electronic monitoring is not perceived as a form of serving a sentence ${ }^{54}$.

However, using electronic monitoring may have two major advantages for the convicted person and for society. First of all, serving one's sentence outside of prison facilitates rehabilitation and the reintegration of the person into society by ensuring that they stay connected to their support environment. Secondly, the convicted person

\footnotetext{
${ }^{47}$ J. Murdoch, The treatment of prisoners. European standards, Strasbourg, Council of Europe Publishing, 2006, p. 15.

48 J. Murdoch, op. cit.

49 Ibidem, p. 210.

${ }^{50}$ See C. Kempinen, Pennsylvania Revises Sentencing Guidelines, august 1997, apud M. Tonry (ed.), Penal Reform in Overcrowded Times, Oxford, New York, Oxford University Press, 2001, pp. 73-79.

51 United Nations Office on Drugs and Crime, Regional Office for Central America and the Caribbean (UNODC ROPAN), The use of electronic monitoring bracelets as an alternative measure to imprisonment in Panama, Technical Advisory Opinion No. 002/2013, addressed to the Public Ministry and the Ministry of Government of Panama, 2013, pp. 1-18.

52 Ibidem, p. 3.

${ }^{53}$ Based on their income, in the case in which they need to bear part of the costs of monitoring or own a mobile telephone/landline.

${ }^{54}$ UNODC ROPAN, The use of electronic monitoring bracelets as an alternative measure to imprisonment in Panama, p. 4.
} 
has much better chances of (maintaining) their integration into the labor market, in order to compensate the victim for the damages incurred ${ }^{55}$.

In order to facilitate the harmonization of rules and mechanisms of electronic surveillance at the international level, the application of non-custodial measures is governed by the Tokyo Rules ${ }^{56}$, which state "the need for systematic assessment in order to ensure the effectiveness of any new type of non-custodial measure". In order to prevent the application of degrading treatment which infringes upon inherent human dignity, articles 3.8, 3.9 and 3.11 of the United Nations Resolution require national authorities to not carry out medical or psychological experiments on convicted persons, and also the obligation of authorities to respect a convicted person's right to privacy, as well as their family's rights. Furthermore, national authorities must ensure that electronic bracelets do not present an "unjustified risk of physical or psychological injury of convicted persons" 57 .

In the European context, the provisions of the Tokyo Rules are supplemented with the Recommendations of the Council of Europe ${ }^{58}$, according to which:

- National legislation must clearly specify the types of offenses, maximum length of sentences for which electronic monitoring may be imposed as well as the arrangements for the implementation of this measure ${ }^{59}$.

- Courts have to rule on decisions regarding imposing or revoking electronic monitoring ${ }^{60}$.

- The application of the measure of electronic monitoring must not restrict "a person's fundamental rights and freedoms to a greater extent than is provided for by the decision to apply it" 61 .

- The interests of third parties at the place of residence of the convicted person should be taken into account when imposing electronic monitoring ${ }^{62}$.

- In order to reduce repeat offense, throughout electronic monitoring, the convicted persons must continue to take part in activities dedicated to social reintegration ${ }^{63}$.

In order to overcome the limitations of using radiofrequency (RF) technology or satellite location (via Global Positioning System), as well as the medical and social effects of wearing an ankle bracelet, the Council of Europe recommends the use of

\footnotetext{
${ }_{55}$ UNODC ROPAN, The use of electronic monitoring bracelets as an alternative measure to imprisonment in Panama, p. 4.

${ }^{56}$ See the United Nations Standard Minimum Rules for Non-custodial measures (The Tokyo Rules) - Adopted by the General Assembly resolution 45/110 of 14 December 1990.

${ }^{57}$ UNODC ROPAN, The use of electronic monitoring bracelets as an alternative measure to imprisonment in Panama, p. 4.

${ }^{58}$ Council of Europe, Scope and definitions electronic monitoring, document by Mike Nellis and Dominik Lehner, the European Committee on crime-related matters, Strasbourg, 16 October 2012, PC-CP (2012) 7 rev 2.

59 Ibidem, p. 3.

60 Ibidem.

61 Ibidem.

62 Ibidem.

${ }^{63}$ Ibidem.
} 


\section{The application of electronic monitoring systems in Romania...}

voice verification, which enables the identification of the location of the convicted person. In the case of minors and juvenile convicted persons, "voice verification represents a more acceptable method of electronic monitoring" as there is no risk of stigmatization or labeling ${ }^{64}$.

Starting from the objective of reducing the high level of penitentiary occupancy, the Committee of Ministers recommends to member states to use electronic monitoring "in a well organized and proportional manner, as to limit potential negative effects on the private and family life of the monitored person and involved third parties $" 65$. Another recommendation that national authorities should consider is to take into account the personal circumstance of every person to whom remote surveillance is applied $^{66}$. Furthermore, communication and cooperation with researchers, NGOs and the media is useful for informing members of the community as well as for identifying the optimal framework for the use of electronic monitoring ${ }^{67}$.

\section{USE OF ELECTRONIC MONITORING IN THE EUROPEAN CONTEXT}

Electronic monitoring is used, currently, in many European countries ${ }^{68}$, the integration of remote surveillance systems being done gradually throughout criminal justice systems. In Europe, France and Britain (England and Wales) represent "models" of good practice, presenting the greatest incidence of the use of electronic monitoring as a primary sanction ${ }^{69}$. Conversely, a different model can be found in Germany, where electronic surveillance is used only in the Land of Hess, without being used in other German Lands or at the federal level ${ }^{70}$.

In order to have an overview of the different implementation strategies for electronic monitoring in Europe, we will analyze, from a comparative perspective, the characteristics of the French, Belgian, Dutch and Swedish models of implementing remote surveillance. Our objective is to highlight the complexity of different strategies regarding electronic monitoring, signaling from the beginning that there is no standard model, no unique, "imperative", recipe which guarantees the success of the application of remote surveillance. On the contrary, the costs and consequences of electronic

\footnotetext{
${ }^{64}$ Council of Europe, Scope and definitions electronic monitoring, document by Mike Nellis and Dominik Lehner, the European Committee on crime-related matters, Strasbourg, 16 October 2012, PC-CP (2012) 7 rev 2, p. 4.

${ }^{65}$ Committee of Ministers, Recommendation (2014)4 to member states regarding electronic monitoring, adopted on 19 February 2014, at the $1192^{\text {nd }}$ reunion of Deputy Ministers.

66 Ibidem.

${ }^{67}$ Ibidem.

${ }^{68}$ In France, Great Britain (England and Wales), Belgium, Denmark, Luxembourg, the Netherlands, Norway, Poland, Spain, Portugal, Italy, Sweden, Switzerland and the Land of Hesse (Germany).

${ }^{69}$ A. Jandrić Nišević, Nena Franić and Saša Rajić, An overview of the research into the effectiveness of electronic monitoring as an alternative sanction, p. 53.

${ }^{70}$ H.-J. Albrecht, Electronic Monitoring in Europe: A Summary and Assessment of Recent Developments in the Legal Framework and Implementation of Electronic Monitoring, Max Planck Institute for Foreign and International Criminal Law, 2005, p. 2.
}

STUDIES AND ARTICLES 
monitoring are influenced, primarily, by the strategy and the steps of implementing remote surveillance as well as on the size of the target group and the criteria for eligibility applied to convicted persons.

In order to explore the early stages of introducing electronic monitoring on a small scale, it is useful to refer to the "French model", characterized by the use of pilot courts to test, in the short term, the consequences of remote surveillance. Presently, in France, there are on average, 20.000 people under surveillance every year, at an average annual inmate flow of 70.000 people $^{71}$. Extending the use of electronic monitoring to 20.000 people was done over time. Introduced at the beginning of the year 2000, electronic monitoring was used experimentally in four pilot courts ${ }^{72}$. Up to the $1^{\text {st }}$ of January 2002 , the four pilot courts had imposed electronic surveillance to 143 convicted persons, with electronic monitoring being then extended to all French courts ${ }^{73}$. From this perspective, the French model offers the possibility of exploring the first steps of a (gradual) introduction of electronic monitoring on a small scale.

A different paradigm for remote surveillance can be identified when referring to the "Belgian model" of electronic monitoring, defined in the early 2000s in the literature ${ }^{74}$ from the perspective of the balance between social support and technical control $^{75}$. The specificity of the "Belgian model" lies in strict eligibility criteria and the prudent attitude of the staff involved, reason for which, during the pilot phase of 1998-2000, just 72 convicted persons were accepted, even if the target group consisted of 300 detainees, with a deficit of 1226 accommodations (corresponding to a $116.4 \%$ occupancy of penitentiaries) ${ }^{76}$. The criteria for eligibility related to the length of the sentence (less than 18 months imprisonment), the convicted person's access to the labor market and participation in educational or therapeutic programs ${ }^{77}$. Presently, the Belgian system of electronic monitoring has moved away from the initial "model", focusing on the control and enforcement dimension of punishment ${ }^{78}$. After the eligibility criteria were waived, electronic monitoring was extended in 2013 to 1318 convicted persons ( $9.7 \%$ of the total prison population $)^{79}$.

\footnotetext{
${ }^{71}$ A. Henneguelle, B. Monnery și A. Kensey, Better at Home than in Prison?, The Effects of Electronic Monitoring on Recidivism in France, pp. 1-2.

72 Ibidem, p. 3.

73 Ibidem, p. 9.

${ }^{74}$ See K. Beyens, R. Bas and D. Kaminski, Elektronisch toezicht in België. Een schijnbaar penitentiair ontstoppingsmiddel, Panopticon, Vol. 28, Nr. (3), 2007, pp. 21-40; K. Beyens and D. Kaminski, Is the Sky the Limit? Eagerness for Electronic Monitoring in Belgium, in M. Nellis, K. Beyens and D. Kaminski (eds.) Electronically Monitored Punishment. International and Critical Perspectives, Oxon, Routledge, 2013, pp. 174-199.

${ }^{75} \mathrm{~K}$. Beyens and M. Roosen, Electronic monitoring in Belgium: a penological analysis of current and future orientations, in European Journal of Probation University of Bucharest, Vol. 5, Nr. 3, 2013, pp. 56-70.

${ }^{76}$ K. Beyens and M. Roosen, op. cit., p. 57.

77 Ibidem.

78 Ibidem, p. 56.

${ }^{79}$ Ibidem, p. 60.
} 


\section{The application of electronic monitoring systems in Romania...}

The cost of using electronic monitoring varies from state to state, but it must be contrasted to the cost necessary to ensure a minimum level of security to the imprisoned person in order to test the economic effects of using electronic monitoring. In the European area, direct costs of electronic monitoring vary from 2 Euros (in Estonia) to 100 Euros (in Norway), but the methodology for calculating costs varies with regard to the types of costs which are taken into account (from monitoring equipment to the entire remote surveillance system $)^{80}$. Also, statistics regarding the costs of electronic monitoring are influenced by the fact that in certain states, part of the costs is borne by the people whom the courts have placed under remote surveillance. In Switzerland and Sweden, this amount varies from 2 to 20 Euros per day ${ }^{81}$.

Electronic monitoring has proved to be a cost effective measure in Belgium, reducing the upkeep costs for convicted persons by a factor of three (from 126 Euros, when serving the sentence in a penitentiary, to 39 Euros, in the case of remote surveillance $)^{82}$. Moreover, redefining remote surveillance by home arrest with voice verification of the convicted person (for a sentence of up to three years in prison), in place of an electronic bracelet, has led to a significant cost reduction, taking daily upkeep costs down from 39 Euros to a mere 5,56 Euros $^{83}$.

As in Belgium, using electronic surveillance allows Sweden to save on the budget necessary for the upkeep of convicted persons. On this point, the Swedish detention model offers a useful example for understanding the long term consequences of using remote surveillance. At a cost of 4 Euros/convicted person/day, the electronic monitoring system (software, hardware and maintenance) - compared to 180 Euros/convicted person/day necessary for ensuring a minimum security level in the prison system - has led to savings of almost 100 million Euros in the 1994-2010 timeframe ${ }^{84}$. Moreover, remote surveillance has facilitated the reintegration of convicted persons into society and the maintaining of the link with their support environment, generating secondary savings through the electronically monitored convicted person's access to the labor market which enabled them to support their family members and contribute taxes ${ }^{85}$.

Furthermore, the percentage ration between the budget allocated to electronic monitoring and the budget necessary to implement criminal justice gives a representative perspective on the low costs of electronic monitoring. Therefore, for

\footnotetext{
${ }^{80}$ M. Kylstad Øster and S. Beumer, EM and Human Rights, 9th European Electronic Monitoring Conference Electronic Monitoring, Probation and Human Rights, Frankfurt/Offenbach, 11-13 December 2014.

${ }^{81} \mathrm{H}$.J. Albrecht, Electronic Monitoring in Europe: A Summary and Assessment of Recent Developments in the Legal Framework and Implementation of Electronic Monitoring, p. 8.

${ }^{82} \mathrm{~K}$. Beyens and M. Roosen, Electronic monitoring in Belgium: a penological analysis of current and future orientations, pp. 58-59.

${ }^{83}$ Ibidem, p. 63.

${ }^{84} \mathrm{~J}$. Bungerfeldt, The use of Electronic Monitoring in Sweden to constrain offenders in home detention, Seminar The Impact of Alternative Sanctions and the Electronic Monitoring, Vilnius (Lituania), 3 March 2011, p. 5.

85 Ibidem.
} 
every 100 Euros allocated for criminal justice, the cost of electronic monitoring is 10 cents in France, 50 cents in Sweden and 80 cents in Great Britain (England and Wales) ${ }^{86}$.

Reducing the prison population and the occupancy levels of penitentiaries is another argument favoring electronic monitoring. In this regard, the Swedish prison system benefitted from a $10 \%$ reduction in its inmate population as a result of using electronic monitoring ${ }^{87}$. We must, however, mention that the reduction of the occupancy level of prisons is not a universal rule, as it is dependent on the stages of the implementation of electronic monitoring from the local to the national level, as well as on the levels of repeat offenses, as well as from the perspective of the convicted persons' reintegration in society. A relevant example in this sense is the rapid generalization of the instrument of remote surveillance in the "Belgian model", which represented one of the factors which led to a long-term increase in penitentiary occupancy levels by $6.3 \%$, from $16.4 \%$ in 2014 to $23.7 \%$ in $2013^{88}$.

At the same time, we identify a wide range of strategies regarding the use of electronic monitoring based on the age of the convicted persons, their offense, their sentence, as well as the average length of remote surveillance ${ }^{89}$. A good practice model is used in the Netherlands ${ }^{90}$ and Sweden ${ }^{91}$, by simultaneously applying two different electronic monitoring strategies: On the one hand, the "front door" model is used for people who have been sentenced to less than 6 months imprisonment, a measure which can be combined with community service ${ }^{92}$. On the other hand, for persons convicted to more than two years in prison, who have served half of their sentence, the "back door" model applies, during which electronic monitoring serves the function of house arrest (corresponding to a low security detention center). In this case, penitentiary administrations are the ones which establish the rehabilitation activities in which the monitored persons must take part. Generally speaking, the rehabilitation program has at least 26 hours a week ${ }^{93}$.

A specific feature of the "Swedish model" regarding the use of the "back door" strategy consists in the evaluation of the risk of repeat offense for convicted persons requesting serving their sentence through remote surveillance. On average, $40 \%$ of requests are denied on the grounds of risks identified in the assessment ${ }^{94}$.

\footnotetext{
${ }^{86}$ H.-J. Albrecht, Electronic Monitoring in Europe: A Summary and Assessment of Recent Developments in the Legal Framework and Implementation of Electronic Monitoring, p. 12.

87 Ibidem.

${ }^{88} \mathrm{~K}$. Beyens and M. Roosen, Electronic monitoring in Belgium: a penological analysis of current and future orientations, p. 65.

${ }^{89}$ See Annex no. 1. The Application of electronic monitoring in the European context.

${ }^{90}$ H.-J. Albrecht, Electronic Monitoring in Europe: A Summary and Assessment of Recent Developments in the Legal Framework and Implementation of Electronic Monitoring, p. 4.

${ }^{91} \mathrm{~J}$. Bungerfeldt, The use of Electronic Monitoring in Sweden to constrain offenders in home detention, Seminar The Impact of Alternative Sanctions and the Electronic Monitoring, Vilnius (Lituania), 3 March 2011, p. 2.

${ }^{92}$ H.-J. Albrecht, Electronic Monitoring in Europe: A Summary and Assessment of Recent Developments in the Legal Framework and Implementation of Electronic Monitoring, p. 4.

93 Ibidem, p. 4.

${ }^{94}$ J. Bungerfeldt, The use of Electronic Monitoring in Sweden to constrain offenders in home detention, Seminar The Impact of Alternative Sanctions and the Electronic Monitoring, Vilnius (Lituania), 3 March 2011, p. 3.
} 


\section{The application of electronic monitoring systems in Romania...}

Prior evaluation of convicted persons leads to a lower rate of repeat offense among those permitted to serve their sentence through electronic monitoring. For example, in 2010, approximately 3700 people were sentenced to house arrest under electronic surveillance: a) 3000 convicted persons were placed under electronic monitoring on the basis of a "front door" strategy, most having been convicted for driving under the influence of alcohol or drug use; b) in the case of 700 persons convicted of drug trafficking or homicide, the "back door" policy was applied, with $35 \%$ of them being placed on house arrest for the latter part of their sentence ${ }^{95}$.

A particular version of the "front door" model is identified in the Belgian criminal system, where the prison director plays a central role in the procedure of commuting a sentence of up to three years imprisonment by placing a convicted person in house arrest without that person having served a single day of their sentence in prison ${ }^{96}$. For custodial sentences of more than three years, the decision regarding placing under electronic monitoring can be taken by the court that delivered the final decision ${ }^{97}$.

\section{DETENTION VS. REINTEGRATION. DIMENSIONS OF PUNISHMENT}

\section{IN THE ROMANIAN SYSTEM}

In the post-communist Romanian space, sociologists Sorin M. Rădulescu and Dan Banciu have made an important contribution to the study of delinquency ${ }^{98}$. The research paradigm of Rădulescu and Banciu is specific to a sociological research of etiological analysis of the phenomenon of delinquency: It places collectivities and communities in the center of the analysis and identifies, within them, the predominant lifestyles, convictions and beliefs; all the while, the individual becomes an isolated element of the analysis. Within the social structure, we can identify the sources of delinquency, reason for which these are dependent on "the nature and quality of the community (improper living conditions, marginal areas, inadequate recreation facilities, low family income etc.)"99.

The first sources of inspiration for Rădulescu and Banciu may be identified among the representatives of normative functionalism and behaviorism, influenced by the conception of the "establishment" of Talcott Parsons, they have offered a different perspective on the way in which individuals relate society's norms. At the center of the theory, we no longer find the individual, but peer pressure, which attempts to impose a

\footnotetext{
$95 \mathrm{~J}$. Bungerfeldt, The use of Electronic Monitoring in Sweden to constrain offenders in home detention, Seminar The Impact of Alternative Sanctions and the Electronic Monitoring, Vilnius (Lituania), 3 March 2011, p. 4.

${ }^{96} \mathrm{~K}$. Beyens and M. Roosen, Electronic monitoring in Belgium: a penological analysis of current and future orientations, p. 59.

97 Ibidem.

${ }^{98}$ S.M. Rădulescu and D. Banciu, Sociologia crimei şi criminalității, București, Casa de editură şi presă "Şansa" S.R.L., 1996, p.12.

${ }^{99}$ Ibidem, pp. 173-174.
}

STUDIES AND ARTICLES 
certain social order, excluding certain behaviors from its expectations, which are "shared or recognized as legitimate in a social system"100. It follows that relating to a social context becomes imperative in order to explain the antinomy between cultural standards and deviant behaviors ${ }^{101}$.

The paradigm shift is accelerated through the work of Émile Durkheim, the first sociologist to define deviance in relation to the social norm. Durkheim's observations ${ }^{102}$ regarding suicide represent a source of understanding for the causes which lead to delinquents who have not been reintegrated into society to commit new offenses.

The dual nature of man is the starting point of Durkheim's elaborate analysis, giving him the opportunity of studying the phenomenon both from the perspective of the "physical man", as well as from the perspective of the "social man"103. Regarding this aspect, we note Durkheim's observation that the social man "needs a society he can express and serve"104. When society disintegrates, mentions Durkheim, "all that is social within us is left lacking an objective foundation"105.

Against the background of disturbances in collective order ${ }^{106}$, we identify an increase in the state of disruption or anomie ${ }^{107}$ of actions carried out by society in order to regulate social relations, reason for which major changes occur on the delinquency curve, the latter suffering from a sharp increase ${ }^{108}$. The state of anomie causes members of the community to relate differently to the provisions of the legal framework. Law and justice become confused as a result of the disruption of the value system of society ${ }^{109}$.

Another filter to which the authors refer is represented by the prevention and treatment of acts of delinquency, highlighting the importance of the re-socialization and moral and social recovery of their authors ${ }^{110}$. Applying this filter, Rădulescu and Banciu position themselves on the side of the supporters of the idea that "detention and deprivation of liberty must serve as a last resort ("ultimo ratio") - and idea found in the majority of criminal justice systems ${ }^{111}$.

Moreover, Rădulescu and Banciu emphasize the fact that regardless of the gravity of the offense, the convicted persons, while serving their custodial sentence, must be guaranteed an optimal framework for re-socialization and subsequent reintegration into

100 W.H. Sprott, Science and Social Action, Glencoe, Illinois, The Free Press, 1966, p. 104, apud S.M. Rădulescu and D. Banciu, op. cit., p. 19.

101 Ibidem, p. 20.

102 É. Durkheim, Despre sinucidere, trad. M. Calcan, Iaşi, Institutul European, 1993 [1897].

103 Ibidem, p. 167.

104 É. Durkheim, op. cit., p. 167.

105 Ibidem.

106 Ibidem, p. 197.

107 Ibidem, p. 205.

108 Ibidem, p. 204.

109 Ibidem.

110 S.M. Rădulescu and D. Banciu, op. cit., p. 224.

111 Ibidem, p. 231. 
The application of electronic monitoring systems in Romania...

society, by ensuring their access to schooling and job training, religious freedom, physical exercise and sports, visits, mail, access to literature, media and professional medical and psychological assistance ${ }^{112}$. Depriving someone of freedom does not mean depriving them of the subsequent right of reintegration and re-socialization, the delinquent preserving, first and foremost, his right to dignity.

"Detention must be limited to depriving the delinquent individual of liberty, without other aggravating circumstances, and it must limit, to the fullest extent possible, psychologically traumatizing inmates, preventing the emergence of emotional distress, obsessive ideas or thoughts of suicide, violence or aggression"113.

In the process of transition, in the context of violent miners' uprisings and a punitive criminal law - which did not provide for the reintegration and re-socialization of convicted persons, Rădulescu and Banciu take, from the judicial doctrine, and the psychological and sociological orientations, the perspective that prisons serve two roles simultaneously: 1) punishing the perpetrators of delinquency by depriving them of freedom; 2) supporting the persons deprived of their freedom in order to reintegrate and re-socialize them after having served their sentence.

Sorin M. Rădulescu and Dan Banciu were the founders of the sociology of deviance in the Romanian space, a field of research banned during the communist regime ${ }^{114}$. Subsequently, this field was overrun by "numerous impostors and amateurs" who "have obtained an undeserved prestige and scientific and academic titles through fraud and deception"115.

Thus, research regarding the phenomenon of delinquency and the prison environment did not see an expansion in the following years, remaining a minor subject of sociological, psychological or political science research. The theory promoted by the two authors, according to which society as a whole is responsible for the emergence of antisocial acts, has not been internalized at a societal level.

\section{MEASURES AND STRATEGIES TO REDUCE PRISON OVERCROWDING}

\section{IN ROMANIA}

Starting from the obligation to comply with respecting the conditions offered to people who are imprisoned, the European Court of Human Rights has repeatedly ruled against Romania for violating the Convention for the Protection of Human Rights and

\footnotetext{
112 S.M. Rădulescu and D. Banciu, op. cit., p. 232.

113 Ibidem, p. 234.

${ }^{114}$ See D. Banciu, O ramură a sociologiei, interzisă în timpul dictaturii: sociologia devianței, Revista română de sociologie, anul XXIV, nr. 5-6, București, 2013, pp. 426-440.

115 D. Banciu, op. cit.
}

STUDIES AND ARTICLES 
Fundamental Freedoms. According to statistics, Romania ranks fourth on the number of decisions ruled against states since 1959 to 2016 with regards to violating the Convention. Out of 1283 Romanian cases on which the European Court has ruled, in 1147 cases (89.39\%), the Court has decided that provisions of the Convention have been violated. Among these, 206 rulings concerned the inhuman or degrading treatment of convicted persons as a result of prison overcrowding ${ }^{116}$.

In order to have an overview of the ECHR jurisprudence, it should be noted that the highest number of rulings were passed against the following countries: Turkey (2889 rulings out of 3270 ), the Russian Federation (1834 rulings out of a total of 1948), Italy (1791 rulings out of a total of 2351) 117 .

Table no. 1. ECHR rulings against Romania in relation to prison occupancy levels ${ }^{118}$

\begin{tabular}{|c|c|c|c|c|c|}
\hline Year & $\begin{array}{l}\text { Total } \\
\text { number of } \\
\text { judgments } \\
\text { finding at } \\
\text { least one } \\
\text { violation of } \\
\text { a right } \\
\text { provised for } \\
\text { by the } \\
\text { ECHR } \\
\text { Convention } \\
\text { or Protocols }\end{array}$ & $\begin{array}{l}\text { Finding } \\
\text { violations of } \\
\text { art. } 3 \text { of the } \\
\text { Convention } \\
\text { ("The } \\
\text { prohibition of } \\
\text { ill-treatment") }\end{array}$ & $\begin{array}{c}\text { Finding } \\
\text { violations } \\
\text { of art. } 6 \text { of } \\
\text { the } \\
\text { Convention } \\
\text { ("The right } \\
\text { to a fair } \\
\text { trial") }\end{array}$ & $\begin{array}{l}\text { Total damages } \\
\text { paid following } \\
\text { rulings of the } \\
\text { Court or } \\
\text { settlements } \\
\text { decisions } \\
\text { (Expressed in } \\
\text { RON) }\end{array}$ & $\begin{array}{c}\text { Penitentiary } \\
\text { occupancy } \\
\text { levels } \\
\text { (calculated } \\
\text { per } 4 \mathrm{~m}^{2} \text {, } \\
\text { expressed } \\
\text { as a } \\
\text { percentage) }\end{array}$ \\
\hline 2003 & 24 & 1 & 30 & $7.618 .048,43$ & 171,88 \\
\hline 2004 & 12 & 1 & 10 & $2.237 .405,39$ & 151,65 \\
\hline 2005 & 21 & 1 & 16 & $2.271 .012,19$ & 147,29 \\
\hline 2006 & 64 & - & 24 & $3.041 .699,77$ & 134,62 \\
\hline 2007 & 88 & 2 & 41 & $14.058 .607,71$ & 120,34 \\
\hline 2008 & 189 & 7 & 77 & $47.185 .480,32$ & 114,63 \\
\hline
\end{tabular}

116 European Court of Human Rights, "Violation by Article and by States (1959-2016)", http://www.echr.coe.int/ Douments/Stats_violation_1959_2016_ENG.pdf.

117 Ibidem.

118 Statistics based on information released on the $2^{\text {nd }}$ of February 2018 by the Governmental Agent Directorate (DAG) of the Ministry of Foreign Affairs at the request registered under L1/874 on the $25^{\text {th }}$ of January 2018. For the level of penitentiary occupancy (those without hospital units and preventive arrest centers), the data was obtained from the statistics published by the National Administration of Penitentiaries, Document de politică publică privind îmbunătățirea condițiilor de detenție, April 2011, pp. 6-7; Administrația Națională a Penitenciarelor, Dinamica Efectivelor. Situația privind capacitatea de cazare a unităților şi efectivelor la 29 decembrie 2017, available at http://anp.gov.ro/informatii/dinamica-efectivelor/, accessed on the 29 $9^{\text {th }}$ of December 2017. 
The application of electronic monitoring systems in Romania...

\begin{tabular}{|r|r|r|r|r|r|}
\hline 2009 & 153 & 14 & 56 & $41.232 .042,65$ & 117,92 \\
\hline 2010 & 135 & 22 & 30 & $48.320 .194,89$ & 123,90 \\
\hline 2011 & 58 & 20 & 9 & $8.554 .194,62$ & 122,25 \\
\hline 2012 & 70 & 25 & 17 & $8.779 .648,68$ & 133,06 \\
\hline 2013 & 83 & 29 & 19 & $8.683 .975,91$ & 134,89 \\
\hline 2014 & 74 & 29 & 18 & $9.191 .283,00$ & 136,33 \\
\hline 2015 & 72 & 27 & 13 & $34.873 .831,47$ & 133,86 \\
\hline 2016 & 71 & 28 & 16 & $16.659 .213,32$ & 134,05 \\
\hline 2017 & 55 & 20 & 11 & $\begin{array}{r}11.440 .640,76 \\
\text { (up to }\end{array}$ & 129,77 \\
& & & & $24.11 .2017)$ & \\
\hline
\end{tabular}

In the 2003-2017 timeframe, we find that the overcrowding of penitentiaries was not the main criterion on which the ECHR ruled against Romania. On the one hand, we notice that the level of prison occupancy registered a significant decrease between 2003 and 2009 , from $171.88 \%$ to $114.63 \%$. During this time, the damages paid by Romania for the violation of Convention provisions grew exponentially, from 7 million to 49 million RON. We explain this increase as a result of the failure to respect the right to a fair trial, which has prevailed in the Court's reasoning in this period. In contrast, in the 2009-2017 period, the situation is reversed: overcrowding and precarious detention conditions are the main criterion on the basis of which the ECHR ruled that "art. 5 of the Universal Declaration of Human Rights was violated", article which states:

"No one shall be subjected to torture or to inhuman or degrading treatment or punishment"119.

"Humanity and respect for the inherent dignity of the human person" is a compulsory part of the treatment that "any person deprived of liberty" must receive; an obligation which Romania took upon itself by ratifying the International Covenant on Civil and Political Rights ${ }^{120}$.

In the claims against Romania, the main complaints concerned the high level of prison occupancy, the unhygienic conditions, insufficient sanitation facilities, poor quality food, as well as the presence of rats and insects in cells ${ }^{121}$.

\footnotetext{
${ }^{119}$ Convention for the Protection of Human Rights and Fundamental Freedoms - Romania ratified the signing of the European Convention on Human Rights on the $20^{\text {th }}$ of June 1994, Universal Declaration of Human Rights.

120 Pactul Internațional cu privire la Drepturile Civile şi Politice, adopted on the $16^{\text {th }}$ December 1966 , ratified by Romania through Decree no. 212/1974.

121 Through claims registered 61464/12, 39516/13, 48231/13 and 68191/13 against Romania, plaintiffs Daniel Arpad Rezmiveș, Laviniu Moșmonea, Marius Mavroian, Iosif Gazsi notified the Court on the $14^{\text {th }}$ September 2012, $6^{\text {th }}$ June 2013, 24 $4^{\text {th }}$ July 2013 and $15^{\text {th }}$ of October, respectively, invoking a breach of Art. 3 of the Convention. The complainants deplored the detention conditions at the Preventative arrest centers of Baia Mare and the Gherla, Aiud, Oradea, Craiova, Târgu-Jiu, Pelendava, Rahova, Tulcea, Iaşi and Vaslui penitentiaries. See Ministry of Justice, "Calendarul de măsuri 2018-2024 pentru soluționarea supra-aglomerării carcerale şi a condițiilor de detenție, în executarea hotărârii-pilot Rezmiveș şi alții împotriva României, pronunțată de CEDO la
} 
Through the pilot ruling of 25 April 2017, the ECHR held that the structural issues of prison overcrowding and inadequate detention conditions has affected and may further affect many persons deprived of liberty ${ }^{122}$. In the Court's view, the Romanian State has a positive obligation - according to article 3 of the Convention - to ensure that persons deprived of freedom are incarcerated in "conditions which are compatible with the respect of human dignity", and that they not be "subjected to suffering or hardship whose intensity exceeds the inevitable level of suffering which is inherent to detention"123.

On the basis of information provided by the Government, the Court found that there was a strong presumption of a worsening of the state of health of imprisoned persons since "the personal space allotted to the plaintiffs was, for the most part of their detention, less than $3 \mathrm{~m}^{2 \prime 124}$. Other than the problem of an "acute lack of space", the Court identified that plaintiffs were subjected to inhuman treatment due to the unsanitary conditions found in detention centers. With regard to the aspects underlined by the plaintiffs, the Government did not contest the lack of ventilation and toilets, while the lack of running water, natural lighting as well as the presence of rats were denied ${ }^{125}$.

For these reasons, the Romanian state was requested to submit, within six months from the date when the decision stayed final, a calendar with legislative, administrative and budgetary measures intended to correct the malfunctions of the Romanian prison system, whose practice is in breach of the principles of the Convention ${ }^{126}$.

As a result of checks ordered in the 2012-2017 period, as a result of the semi-pilot ruling in the case of lacov Stanciu v. Romania (application no. 35972/05), the Penitentiary Inspection Directorate of the National Penitentiary Administration (DIP-ANP) discovered the existence of a high level of penitentiary occupancy levels and/or the existence of inadequate detention conditions in 30 penitentiaries ${ }^{127}$.

25 aprilie 2017", approved in the Government meeting of $17^{\text {th }}$ January 2018, pp. 1-21, accessed on $11^{\text {th }}$ February 2018, available at: http://www.just.ro/calendarul-de-masuri-2018-2024-pentru-solutionarea-supraaglomerarii-carcerale-si-a-conditiilor-de-detentie-in-executarea-hotararii-pilot-rezmives-si-altii-impotriva-roma niei-pronuntata-de/.

122 See Cour Européenne des Drois de l'Homme, Quatrième section, Affaire Rezmiveş et autres c. Roumanie (Requêtes nos 61467/12, 39516/13, 48231/13 et 68191/13), Arrêt, Strasbourg, 25 April 2017, accessed on 11 th February 2018, available at: http://juri.ro/static/files/2017/aprilie/25/AFFAIRE_REZMIVE_ET_AUTRES_c._ ROUMANIE.pdf.

123 Ibidem.

124 Ibidem.

125 Ibidem.

${ }^{126}$ Ministry of Justice, “Calendarul de măsuri 2018-2024 pentru soluționarea supra-aglomerării carcerale şi a condițiilor de detenție, în executarea hotărârii-pilot Rezmiveș și alții împotriva României, pronunțată de CEDO la 25 aprilie 2017 ", p. 3.

127 The existence of overcrowding and/or inadequate detention conditions was observed in the following penitentiaries: Bistrița, Botoşani, C.E. Buziaș, Mărgineni, Giurgiu, Spital Rahova, Timişoara, Vaslui, PMT Craiova, Craiova, C.R. Tg. Ocna, Gherla, Târgşor, Tulcea, Slobozia, Spital Tg. Ocna, Tg. Mureş, Penitenciarul Jilava, CD Tichilești, Aiud, Giurgiu, Oradea, D.-T. Severin, Codlea, Poarta Albă, Baia Mare, Craiova, Găeşti, Satu Mare, Tg. Jiu. 
The application of electronic monitoring systems in Romania...

The issue of prison overcrowding persists, according to data presented in the Ministry of Justice's Calendar of Measures. Therefore, on the $8^{\text {th }}$ of January 2017, the average occupancy level in penitentiaries was $121.54 \%$, with 23491 persons incarcerated, in a prison system with a nominal capacity ${ }^{128}$ of $18790^{129}$, as follows:

Table no. 2. Allocation of imprisoned persons according to the penalty regime $8^{\text {th }}$ January $2017^{130}$

\begin{tabular}{|l|l|l|l|l|l|}
\hline $\begin{array}{c}\text { Detention } \\
\text { regime }\end{array}$ & $\begin{array}{c}\text { Incarcerated } \\
\text { persons }\end{array}$ & $\begin{array}{c}\text { Accommodation } \\
\text { capacity } \\
\text { per } \mathbf{4} \mathbf{~}^{\mathbf{2}}\end{array}$ & $\begin{array}{c}\text { Accommodation } \\
\text { capacity } \\
\text { per } \mathbf{3} \mathbf{~ m}^{\mathbf{2}}\end{array}$ & $\begin{array}{c}\text { Accommodation } \\
\text { deficit } \\
\text { per } \mathbf{4} \mathbf{~ m}^{\mathbf{2}}\end{array}$ & $\begin{array}{c}\text { Accommodation } \\
\text { deficit } \\
\text { per } \mathbf{3} \mathbf{~}^{\mathbf{2}}\end{array}$ \\
\hline $\begin{array}{l}\text { Maximum } \\
\text { security }\end{array}$ & 1.499 & 1.651 & 2.306 & - & - \\
\hline Closed & 6.324 & 5.237 & 7.057 & 1.087 & - \\
\hline Semi-open & 8.361 & 5.348 & 7.155 & 3.013 & 1.206 \\
\hline Open & 3.554 & 3.603 & 4.810 & - & - \\
\hline
\end{tabular}

In order to understand the dynamics of the occupancy levels in prisons, it is useful to relate to the deficit of detention capacity (relative to the accommodation capacity per $4 \mathrm{~m}^{2}$ ), as well as to the number of cases registered for surveillance in the probation system ${ }^{131}$. In the 2012-2017 period, the detention capacity deficit dropped significantly, from 18000 to 4300 (an estimated need), while the number of cases registered in the probation system increased in the same timeframe from 20000 to $100000^{132}$.

\footnotetext{
${ }^{128}$ Capacity relative to a space of $4 \mathrm{~m}^{2}$ per inmate, not counting space destined for hospital penitentiaries.

129 Ministry of Justice, “Calendarul de măsuri 2018-2024...”, p. 3.

130 Information from the Ministry of Justice, “Calendarul de măsuri 2018-2024...”, p. 11.

131 "The parole system, as a public service of national interest, contributes to the delivery of justice and is used for the social rehabilitation of convicted persons, for decreasing the risk of repeat offenses and for maintaining community safety, as well as for the reduction of the social costs of serving a sentence or other penal measures, by lowering the prison population and capitalizing on the socioeconomic potential of convicted persons. In Romania, the parole system is represented by the National Directorate for Parole, a public institution with legal personality within the Ministry of Justice, which works at a central level, and 42 territorial structures, named probation services." - http://www.just.ro/directia-nationala-de-probatiune.

${ }^{132}$ Ministry of Justice, “Calendarul de măsuri 2018-2024 ...", p. 4.
}

STUDIES AND ARTICLES 
Table no. 3. Management of penitentiary units and accommodation numbers in 2012-2016 ${ }^{133}$

\begin{tabular}{|c|c|c|c|c|c|c|}
\hline 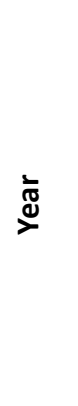 & 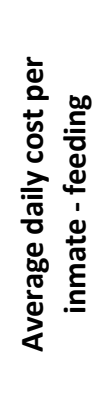 & 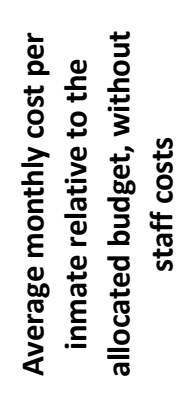 & 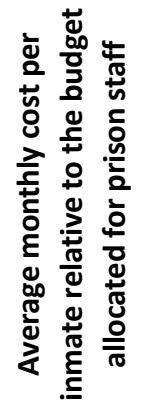 & 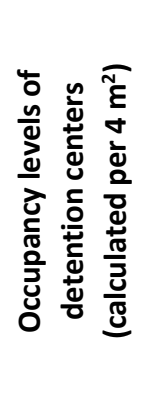 & 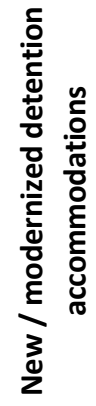 & 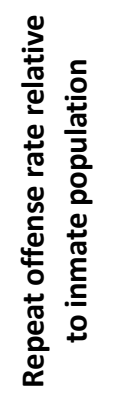 \\
\hline 2012 & 3,76 & 883,84 & $1.612,24$ & $133,06 \%$ & 1.201 & $45,78 \%$ \\
\hline 2013 & 3,76 & 831,87 & $1.766,21$ & $134,89 \%$ & 1.421 & $45,78 \%$ \\
\hline 2014 & 3,76 & 919,3 & $1.863,45$ & $136,33 \%$ & 145 & $43 \%$ \\
\hline 2015 & 3,76 & $1.118,92$ & $2.250,89$ & $133,86 \%$ & 300 & $40,33 \%$ \\
\hline 2016 & - & $1.316,51$ & $2.215,91$ & $134,05 \%$ & 679 & $38,27 \%$ \\
\hline
\end{tabular}

Even though the detention capacity was increased by 3746 , the occupancy levels of penitentiaries (calculated per $4 \mathrm{~m}^{2}$ ) recorded only insignificant fluctuations, while the rate of repeat offense dropped from $45.78 \%$ to $38.27 \%$. The explanation we identify concerns the National Penitentiary Administration's inefficiency in dealing with the issue of overcrowding and ensuring minimal conditions and food to incarcerated persons.

Moreover, the increase of the National Penitentiary Administration's budget led to increased staff costs, the average daily food allocation per inmate remaining 3.76 lei, while the average monthly cost includes heating, water, fuel, medicine, maintenance, furniture and maintenance products costs. Therefore, despite the "progress" of the last 5 years, inmates still lack food and adequate space.

Conversely, the entry into force of the criminal system reform, starting $1^{\text {st }}$ of February 2014, implied a legislative effort aimed at modernizing provisions of the legal framework, spread out over a period of over 10 years ${ }^{134}$. The legislative reform package aimed at reducing prison populations and improving detention conditions.

\footnotetext{
133 Information taken from the National Penitentiary Administration's annual activity reports of 2012-2016. See Administrația Națională a Penitenciarelor, Rapoartele anuale de activitate pentru perioada 2012-2016, available at http://anp.gov.ro/despre-anp/rapoarte-si-studii, accessed on $3^{\text {rd }}$ January 2018.

134 In this period, a new Penal Code, a new Penal Procedure Code as well as three Laws: Law nr. 253/2013 regarding the serving of sentences, educative measures and other non-custodial measures ordered by judicial bodies during criminal proceedings; Law 254/2013 regarding the serving of sentences and custodial measures ordered by judicial bodies during criminal proceedings, as well as Law 252/2013 regarding the organization and functioning of the parole system were passed. See the Ministry of Justice, “Calendarul de măsuri 2018-2024...", p. 5 .
} 


\section{The application of electronic monitoring systems in Romania...}

Until the pilot decision was ruled, the penitentiary system received an additional 672 accommodations in the year 2016, while 2017 saw the creation of a further 170. Furthermore, through the Norwegian Financial Mechanism, another 200 accommodations were modernized in the Bacău Penitentiary ${ }^{135}$. After the pilot decision was ruled, the Government approved, through Decision No. 626/2017, a feasibility study aimed at building P47-Berceni, a new detention center with a planned capacity of 1000 people. For the 2019-2023 period, the increase of detention capacity by 5110 is planned, the funds necessary to start the works having been provisioned for in the 2018 budget $^{136}$.

Through Law 169/2017 regarding the modification and supplementation of Law no. 254/2013, a new compensation mechanism was established, which considers 6 days of a sentence having been carried out by a person imprisoned for 30 days in inadequate detention centers ${ }^{137} .156$ out of the total of 187 detention centers were found to be inadequate (representing $83 \%$ ) by the Order of the Minister of no. $2773 / 2017^{138}$.

Based on the provisions of Law no. 169/2017, between the $19^{\text {th }}$ of October - and the $30^{\text {th }}$ of December 2017, 912 persons were released from prison; with a further 2718 persons released on parole as a result of court rulings ${ }^{139}$. The application of Law $169 / 2017$ had only a low impact on the occupancy levels of penitentiaries as the occupancy index (per $4 \mathrm{~m}^{2}$ ) dropped only $7 \%$, from $136.88 \%$ to $129.77 \%{ }^{140}$.

Although progress has been made with regard to the reduction of detention accommodation deficit, coupled with an increase to the number of people placed on probation, we find that the number of incarcerated persons, as well as the occupancy levels of penitentiaries have not decreased significantly in the 2012-2017 timeframe, reason for which overcrowding and inadequate conditions remain a structural problem of the prison system.

The legislative solution identified by the Ministry of Justice aims at extending the legal framework which allows a judge to individualize the execution of a sentence

\footnotetext{
135 Ministry of Justice, “Calendarul de măsuri 2018-2024...”, p. 8.

136 Ibidem.

137 "For the purposes of this law, serving a sentence in inadequate conditions is understood as being lodged in any of the following situations:

a) lodgings that allow for less than $4 \mathrm{~m}^{2}$ per inmate, which is calculated, excluding sanitation and food storage areas, by dividing the total surface area of the detention area to the number of inmates therein lodged, regardless of the lodging's other equipment;

b) lack of access to outdoor activity;

c) lack of natural lighting or adequate ventilation;

d) inadequate room temperature;

e) impossibility of using a toilet privately and a lack of basic sanitary rules, as well as hygiene requirements;

f) Infiltrations, dampness or mould on detention room walls.", in Ministry of Justice, "Calendarul de măsuri 2018-2024..., p. 19.

138 Ministry of Justice, “Calendarul de măsuri 2018-2024 ...”, p. 8.

139 Ibidem, p. 9.

${ }^{140}$ See Administrația Națională a Penitenciarelor, Dinamica Efectivelor. Situația privind capacitatea de cazare a unităților şi efectivelor la 29 august şi 29 decembrie 2017, available at http://anp.gov.ro/informatii/dinamicaefectivelor, accessed on $1^{\text {st }}$ of September and $29^{\text {th }}$ of December 2017.
}

STUDIES AND ARTICLES 
through remote surveillance by the end of the second semester of $2018^{141}$. Another modification aims at clarifying the interpretations given in practice by the courts with regard to the fulfillment of conditions for parole on "forming the court's conviction that the convicted person has been rehabilitated and can reintegrate into society"142. On the basis of court rulings regarding parole requests, received from appellate courts, the Minister of Justice proposes the elaboration, during the first trimester of 2018, of an analysis with regard to the opportunity of promoting, with regard to parole requests, recourse in the interest of the law ${ }^{143}$.

The legislative package is complemented with the plan regarding penitentiary investments, which foresees for the 2018-2024 timeframe "the creation of 8095 new prison accommodations and the modernization of a further 1351", financed by the Norwegian Financial Mechanism, the State budget, as well as loans from an International Financial Institution ${ }^{144}$. The total amount estimated by the Ministry of Justice for infrastructure investments is in excess of 97 million Euros ${ }^{145}$.

What we can notice is an uneven distribution of the construction plans for new accommodations and the modernization of the existing ones. Therefore, for the year 2018, the Ministry of Justice's objective is to build an additional 316 accommodations and to modernize 500 existing ones. For the 2019-2020 timeframe, the investment plan in the physical infrastructure of penitentiaries foresees a number of 44 new accommodations (all programmed for 2020). Furthermore, the considerable investments regarding the construction of an additional 6727 accommodations and the modernization of another 666 existing ones is planned for $2022-2023^{146}$.

With regard to the distribution of the construction of new accommodations per penitentiary, we note that it does not actually correspond to penitentiary needs relative to their accommodation deficit and occupancy levels (calculated per $4 \mathrm{~m}^{2}$ ). Concretely, the Investment Plan improperly allocates the construction of 200 new accommodations in Aiud Penitentiary (zero deficit, occupancy index of $97.77 \%$ - calculated per $4 \mathrm{~m}^{2}$ ), 320 new accommodations for Deva Penitentiary (0; 77.09\%), 310 new accommodations in Mioveni Penitentiary (0; 84.2\%), 192 in Găeşti Penitentiary (20; 104.71\%), as well as 300 new accommodations in Gherla penitentiary $(110 ; 116.79 \%)$. These penitentiaries do not have, currently, a high level of occupancy, showing low accommodation deficit indexes. However, for Constanța's Poarta Albă and Vaslui Penitentiary, the Ministry of

\footnotetext{
141 Ministry of Justice, “Calendarul de măsuri 2018-2024...”, pp. 11-12.

142 Provisions of art. 551 para. (1), art. 59 para. (1) and art. 591 para. (1) of the previous Penal Code, respectively of art. 99 para. (1) let. d) and art. 100 para. (1) let. d) of the current Penal Code.

143 Ministry of Justice, “Calendarul de măsuri 2018-2024...”, p. 12.

${ }^{144}$ See Government of Romania, MEMORANDUM cu tema: Decizie privind oportunitatea finanțării infrastructurii fizice a sistemului penitenciar român, printr-un proiect finanțat din fonduri externe rambursabile, adopted in the Government meeting of 6 decembrie 2017.

145 Ibidem, pp. 13-14.

146 See Annex no. 2. The investment plan in the physical infrastructure of penitentiaries in the 2018-2024 timeframe.
} 


\section{The application of electronic monitoring systems in Romania...}

Justice is allocating insufficient accommodations to cover the high deficit and lower the occupancy level: for Poarta Albă the plans are to build 300 new accommodations (425; 148.08\%), while for Vaslui only 210 new accommodations are planned (289; $146.54 \%)^{147}$.

\section{IMPLEMENTING ELECTRONIC MONITORING IN ROMANIA:}

\section{HOW AND IN WHAT CONDITIONS?}

Proposed as a legislative solution for the second semester of 2018 , the measure of electronic surveillance is not defined in the 2018-2024 Calendar developed by the Ministry of Justice. The lack of clarification regarding changes envisioned in the legal framework prevents us from making a pertinent analysis of the impact of the measure of remote surveillance. By correlating the succinct presentation of the legislative proposal on electronic monitoring with the comprehensive plan for the construction and modernization of detention accommodations ${ }^{148}$, we note the different approach to these two measures on the part of the Ministry of Justice. In particular, the Ministry of Justice only refers to the objective of regulating the legal framework, without clarifying if the modifications will be done through Emergency Ordinance or by a Draft Law. In addition, the Ministry of Justice avoids assuming a concrete calendar for the implementation of the measure, as well as for defining the target group of beneficiaries.

Referring to other "good practice models" presented in this article, we aim to draw the attention of the legislators and of the Ministry of Justice to the fact that electronic monitoring represents, rather, a tool for the serving of one's sentence, dependent on the regulations and implementation strategies envisioned for it. For this reason, the simple succinct mention of the objective of changing the legal framework prevents us from carrying out a critical assessment of the necessity for the implementation of the Ministry of Justice's strategy for the reduction of the occupancy levels of penitentiaries. Such an analysis could only be done when the Ministry of Justice presents the actual measures it considers.

However, we consider that it would be appropriate for the Ministry of Justice to take into account, when designing and applying the strategy regarding remote electronic monitoring, the following recommendations, based on the "good practice" models presented throughout this article, as follows:

1) Exploring the consequences of using electronic monitoring on a small scale, by testing it in pilot courts for a period of two to five years. This measure should apply to

\footnotetext{
${ }^{147}$ See Annex no. 2. The investment plan in the physical infrastructure of penitentiaries in the 2018-2024 timeframe.

${ }^{148}$ In the "Calendar of measures...", the Ministry of Justice presents the stages of implementing measures regarding the construction and modernization of penitentiaries, the distribution of accommodations per detention units as well as the budget and source of finance.
}

STUDIES AND ARTICLES 
courts located near penitentiaries with a high level of occupancy, which does not allow them to insure the $4 \mathrm{~m}^{2}$ per inmate minimum space. In this case, selecting pilot courts would not be done in a discriminating manner, but by virtue of insuring a compensating measure in order to prevent the serving of one's sentence in inappropriate conditions. Extending the use of electronic monitoring on a national level must be done gradually, with regard to the dynamics of the occupancy levels of penitentiaries.

2) The eligibility criteria for convicted persons for remote surveillance must be clearly defined, with regard to the age of the convicted persons, their offense, the average length of electronic monitoring, the convicted person's access to the labor market, participation to educational or therapeutic programs etc.

3) Pre-assessment of eligible persons and conducting social investigations at their homes by the prison's social workers. It is necessary to obtain the family's consent for the use of electronic surveillance (and the specific rules associated with it) in the case they live with the convicted person.

4) The application of electronic monitoring must be defined by starting from the "front door" model (in the case of people who have a sentence of less than 6 months in prison), and the "back door" model respectively (for convicted persons serving more than two years in prison, who have already served half of their sentence). Proportional to the seriousness of the offense, the remote surveillance program must include the convicted person's participation in reintegration activities, as well as his bearing of part of the cost of monitoring.

5) Using electronic surveillance must aim at maintaining the balance between social support and technical control. Throughout the remote surveillance period, the convicted person's right to confidentiality and private life, as well as that of his family, must be insured. Moreover, remote surveillance must not lead to the institution of a more severe punishment with regard to the sanction ruled by the courts for the committed offenses.

6) Informing citizens, the media and NGOs with regard to the steps, provisions, advantages and costs of implementing electronic monitoring. Cooperating with academics, NGOs and the media is useful for informing members of the community as well as for identifying the optimal framework for the use of electronic monitoring.

7) Estimating the financial and social costs of using electronic surveillance and contrasting them with the costs of detention.

Otherwise, the application of electronic monitoring will be contested by both the media as well as civil society, whose interest, fears and dissatisfactions will manifest in 


\section{The application of electronic monitoring systems in Romania...}

close relation to the notoriety of public figures that would benefit from the measure of remote surveillance, as well as in relation to the publicizing of repeat offense cases. For this reason, the above mentioned recommendations aim at reintegrating convicted persons, who have been sentenced to electronic monitoring by the courts, into society without disturbing the social order within the community.

\section{CONCLUSIONS}

At the end of this research, we find strong articulation between using alternative forms of punishment and the degree of a person's reintegration into society. Throughout this research we have pointed out that using social inquiries and a gradual use of electronic monitoring (by testing it in pilot courts), contributes to a decrease in upkeep costs for convicted persons as well as maintaining a low level of repeat offense among beneficiaries.

Starting by questioning the limits of using electronic monitoring, we note that the design and the stages of implementing the measure of remote electronic surveillance determines the (in)effectiveness of this measure.

In the Romanian case, sudden changes to the institutional design of criminal policy have occurred without adequate debates and evaluations from academia or custodial institutions, reason for which the improvement of detention conditions and reductions in occupancy levels of penitentiaries happen only in the short term.

In this context, we have identified a lack of internalization of the theory promoted by founders of the sociology of deviance, Sorin M. Rădulescu and Dan Banciu. In the Romanian academic environment, research regarding criminality and the prison environment has not been expanded in the following years, remaining a marginal subject of research for sociology, psychology and political science. Therefore, despite the efforts of the two researchers, at the core of approaches "labeling" acts as being delinquent, we note that responsibility is placed on individuals and not society as a whole.

Referring to policies and best practice models regarding the use of electronic monitoring, we have exemplified the long-term inefficiency of measures provisioned in the Calendar of measures put forth by the Ministry of Justice. By implementing remote monitoring in the absence of social inquiries and a testing of the measure through pilot courts, the redefining of the Social Contract is done suddenly, top-down, without identifying citizens' concerns and expectations. Moreover, the Ministry's strategy regarding the building of new detention accommodations does not correspond with penitentiaries' actual needs, relative to their accommodation deficit and occupancy index (calculated per $4 \mathrm{~m}^{2}$ ).

Lacking consensus, imposing remote monitoring will be perceived by convicted persons as an extension of social control which endangers the right to confidentiality of 
a convicted person as well as that of his family. Furthermore, public opinion will challenge the removal of the punitive function of punishment, considering that the safety of members of the community is in fact affected.

For these reasons, throughout this research we have adhered to the observation of researcher lan Brownlee, who argues that using electronic monitoring must not be perceived as a "technological magic bullet". In order to reduce the level of occupancy in penitentiaries, the application of remote surveillance must be done gradually, in order to allow for the individualization of punishment and a prior appraisal of convicted persons.

Analyzing different strategies for the implementation of electronic monitoring in the European case, we have proven the fact that in the application of the measure, the interest of safeguarding the community must prevail, along with facilitating the convicted person's reintegration into society by maintaining links with his support environment. In order to reduce the levels of repeat offense among people who serve their sentence under house arrest, we have identified a wide range of exclusion criteria, based on: the seriousness of the offense; the convicted person's behavior during detention; situations in which the convicted person will live together with the victim; mental health issues which affect the self-control of convicted persons; the victim's refusal of accepting the measure.

In addition, throughout this research, we note the fact that there is a direct relation between the costs and consequences of remote monitoring with regard to the strategies and stages of implementation, as well as with regard to the size of the target group and the eligibility criteria applied to convicted persons.

In order to have an overview of the complex implications of remote monitoring, we have observed a wide variety of strategies regarding the use of electronic surveillance with regard to the age of convicted persons, their offense, their sentence, as well as the average time of surveillance.

The main "good practice model" to which we have related is the one used in the Netherland and Sweden, characterized by the application of two different strategies for electronic monitoring: a) the "front door" model, used for persons who have been sentenced to less than 6 months imprisonment, a measure which can be combined with community service; and b) the "back door" model, used in the case of persons convicted to more than 2 years imprisonment, who have already served half of their sentence.

Referring to the Romanian context, we have proven that prison overcrowding was not, during the 2003-2009 period, the main criterion on which the ECHR based its rulings against Romania. In this period, most applications saw the ECHR sanction Romania for not respecting the right to a fair trial. After 2009, shortly after Romania joined the European Union, the ratio was inverted.

Although it aims at reducing prison occupancy levels, the legislative package developed by the Ministry of Justice is not founded on a solid strategy. First of all, the plans for the construction of new detention accommodations and the modernization of

CONSTITUTIONAL LAW REVIEW 


\section{The application of electronic monitoring systems in Romania...}

existing ones does not take into account the actual needs of penitentiaries, relative to their accommodation deficit and their occupancy index (calculated per $4 \mathrm{~m}^{2}$ ). Secondly, although mentioned as a legislative solution for the second semester of 2018, the application of electronic monitoring is not defined in the Calendar of measures developed by the Ministry of Justice.

In order to support the Ministry, we have issued a series of recommendations regarding the development and application of electronic monitoring measures, as follows:

- Pre-testing electronic monitoring on a small scale, through its use in pilot courts.

- The gradual extension of the use of electronic monitoring from pilot courts to all Romanian courts.

- Defining eligibility criteria of convicted persons who can benefit from remote surveillance (with regard to their age, their offense, their sentence, the average length of surveillance, the convicted person's access to the labor market, participation in educational and therapeutic programs etc.).

- Evaluating eligible persons in advance and the conducting of social inquiries at their domicile by the penitentiary's social worker.

- The obligation to get the express acceptance of family members for the measure of remote surveillance (and for its specific rules), if they live with the convicted person.

- Using the "front door" model (in the case of persons who have been sentenced to less than six months imprisonment) and of the "back door" model, respectively (for persons who have been sentenced to more than two years imprisonment and have served half of their sentence).

- Proportionally to the seriousness of the offense, the remote surveillance program must include the convicted person's participation in reintegration activities, as well as his bearing of part of the cost of electronic surveillance.

- Throughout the entire time of electronic surveillance, the right to confidentiality and private life of the convicted person and his family must be ensured.

- Remote surveillance must not lead to the application of a more severe punishment relative to the sentence imposed by the court for the offense.

- Informing citizens, the media and NGOs with regard to the stages, provisions, advantages and costs of implementing electronic monitoring.

- Estimating financial and social costs of the use of electronic monitoring relative to the costs of detention.

Synthesizing, the originality of this research is placing the evolution of criminal justice policies relative to the way society defines deviant acts, in the context of transition and of the reformation of the institutions of the rule of law. This approach differs from other research on the Romanian case through the fact that it manages to identify the dynamics of the occupancy levels of penitentiaries relative to the 
(re)definition of custodial sentences. In order to identify the way in which the inmate is viewed and represented in the prison system, we have supplemented the analysis of criminal justice policies with the interpretation of data available in the statistics of the National Administration of Penitentiaries.

This research is an important instrument for specialists and people involved in the construction and implementation of criminal justice policies, offering a useful analysis of the multiple aspects of electronic monitoring. Through this endeavor, we strive to open the way for new approaches regarding the complex subject of remote monitoring, occupancy levels of penitentiaries and detention conditions.

Annex no. 1. The application of electronic monitoring in the European context ${ }^{149}$

\begin{tabular}{|c|c|c|c|c|c|}
\hline & Sweden & England/Wales & \begin{tabular}{|c|} 
The \\
Netherlands \\
\end{tabular} & Heese/Germany & France \\
\hline $\begin{array}{l}\text { Average length } \\
\text { (months) }\end{array}$ & 1,3 & 3,1 & 3,5 & 4,6 & $\begin{array}{l}85 \% \\
\text { under } 4 \\
\text { months }\end{array}$ \\
\hline $\begin{array}{l}\text { Repeat offense rate } \\
(\%)\end{array}$ & 11 & 18 & - & - & - \\
\hline Age (average) & 37 & 27 & 34 & - & under 35 \\
\hline $\begin{array}{l}\text { Convicted for rape } \\
(\%)\end{array}$ & 5 & 11 & 16 & - & - \\
\hline $\begin{array}{l}\text { Convicted for use of } \\
\text { drugs (\%) }\end{array}$ & 5 & 3 & 20 & 40 & 16 \\
\hline $\begin{array}{l}\text { Convicted for theft } \\
(\%)\end{array}$ & 2 & 17 & 19 & - & - \\
\hline \begin{tabular}{|l|} 
Convicted for \\
violent offenses (\%)
\end{tabular} & 21 & 12 & 22 & 15 & 15 \\
\hline $\begin{array}{l}\text { Minimum-maximum } \\
\text { period (months) }\end{array}$ & $0,5-2$ & $<6$ & $1-6$ & $<6$ & $1-3$ \\
\hline
\end{tabular}

${ }^{149}$ See CEP: Electronic Monitoring in Europe; Brottsförebyggande radet: Intensivövervakning med elektronisk kontroll. Et utvärdering av 1997 och 1998 ars riksomfattande försöksverksamhet. Stockholm 1999; E. Spaans, Electronic Monitoring: The Dutch Experiment. CEP-Bulletin June 1998, pp. 6-8; E. Mortimer, Ch. May, Electronic Monitoring in Practice: The Second Year of the Trials of Curfew Orders. London, 1998; Max-Planck-Institut für Ausländisches und Internationales Strafrecht: Laboratoire Europeen Associee. Bilanz (1998-2001) und Perspektiven (2002-2006). Freiburg 2002, pp. 28-29; Swedish National Council on Crime Prevention: Electronic Tagging in Sweden. Report 2005: 8, p. 19, apud H.-J. Albrecht, "Electronic Monitoring in Europe: A Summary and Assessment of Recent Developments in the Legal Framework and Implementation of Electronic Monitoring", pp. 1-17, available at: https://www.mpicc.de/files/pdf1/albrecht.pdf.

\section{CONSTITUTIONAL LAW REVIEW}


The application of electronic monitoring systems in Romania...

Annex no. 2. The investment plan for the physical infrastructure of penitentiaries in the 2018-2024 timeframe tim $^{150}$

\begin{tabular}{|c|c|c|c|c|c|c|}
\hline $\begin{array}{l}\text { Funding } \\
\text { source }\end{array}$ & $\begin{array}{l}\text { Number of new } \\
\text { accommodations }\end{array}$ & \multicolumn{2}{|c|}{$\begin{array}{c}\text { Number of } \\
\text { modernized } \\
\text { accommodations }\end{array}$} & \multicolumn{2}{|c|}{$\begin{array}{l}\text { Total number of } \\
\text { accommodations }\end{array}$} & $\begin{array}{c}\text { Estimated } \\
\text { value (Euros) }\end{array}$ \\
\hline $\begin{array}{l}\text { The } \\
\text { Norwegian } \\
\text { Financial } \\
\text { Mechanism }\end{array}$ & 1.400 & \multicolumn{2}{|l|}{100} & \multicolumn{2}{|l|}{1.500} & 21.947 .400 \\
\hline State Budget & 4.795 & \multicolumn{2}{|l|}{1.251} & \multicolumn{2}{|l|}{6.046} & 75.297 .550 \\
\hline $\begin{array}{l}\text { Loan from an } \\
\text { International } \\
\text { Financial } \\
\text { Institution }\end{array}$ & 1.900 & - & & \multicolumn{2}{|l|}{1.900} & - \\
\hline $\begin{array}{l}\text { Development } \\
\text { schedule }\end{array}$ & \multicolumn{2}{|c|}{$\begin{array}{l}\text { Number of new } \\
\text { accommodations }\end{array}$} & \multicolumn{2}{|c|}{$\begin{array}{c}\text { Number of } \\
\text { modernized } \\
\text { accommodations }\end{array}$} & \multicolumn{2}{|c|}{$\begin{array}{l}\text { Total number of } \\
\text { accommodations }\end{array}$} \\
\hline 2018 & \multicolumn{2}{|l|}{316} & \multicolumn{2}{|l|}{500} & \multicolumn{2}{|l|}{816} \\
\hline 2019 & \multicolumn{2}{|l|}{-} & \multicolumn{2}{|l|}{-} & \multicolumn{2}{|l|}{-} \\
\hline 2020 & \multicolumn{2}{|l|}{44} & \multicolumn{2}{|l|}{-} & \multicolumn{2}{|l|}{44} \\
\hline 2021 & \multicolumn{2}{|l|}{508} & \multicolumn{2}{|l|}{85} & \multicolumn{2}{|l|}{593} \\
\hline 2022 & \multicolumn{2}{|l|}{3997} & \multicolumn{2}{|l|}{666} & \multicolumn{2}{|l|}{4663} \\
\hline 2023 & 2730 & & - & & 2730 & \\
\hline 2024 & 500 & & - & & 500 & \\
\hline Distribution of $t$ & e construction of $n$ & w accor & odations & & & \\
\hline Penitentiary & $\begin{array}{l}\text { Number o } \\
\text { accommod }\end{array}$ & $\begin{array}{l}\text { new } \\
\text { tions }\end{array}$ & $\begin{array}{r}\text { Accom } \\
\text { deficit } \\
\text { pe }\end{array}$ & $\begin{array}{l}\text { nodation } \\
\text { alculated } \\
4 \mathrm{~m}^{2} \text { ) }\end{array}$ & $\begin{array}{r}\text { Occl } \\
\text { (calcul }\end{array}$ & $\begin{array}{l}\text { lpancy index } \\
\text { ated per } 4 \mathrm{~m}^{2} \text { ) } \\
(\%)\end{array}$ \\
\hline Aind & 200 & & - & & 97,77 & \\
\hline Baia-Mare & 420 & & 114 & & 146,15 & \\
\hline Bistrița & 600 & & 107 & & 131,47 & \\
\hline Botoşani & 400 & & 275 & & 151,02 & \\
\hline Codlea & 80 & & 141 & & 146,38 & \\
\hline Constanța & & & & & & \\
\hline
\end{tabular}

150 Based on information processed from the Ministry of Justice’s “Calendarul de măsuri 2018-2024 pentru soluționarea supra-aglomerării carcerale şi a condițiilor de detenție, în executarea hotărârii-pilot Rezmiveș şi alții împotriva României, pronunțată de CEDO la 25 aprilie 2017", approved in Government meeting on the 17th of January 2018; The National Penitentiary Administration's “Situația privind capacitatea de cazare a unităților şi efectivelor acestora la data de 16 ianuarie 2018", accessed on 16 $6^{\text {th }}$ February 2018, available at: http://anp.gov.ro/wp-content/uploads/2017/06/16.01.2018-Capacitatea-de-cazare-a-unitatilor-si-efectivele-ace stora.pdf. 
Vladimir-Adrian COSTEA

\begin{tabular}{|c|c|c|c|}
\hline $\begin{array}{l}\text { Poarta } \\
\text { Albă }\end{array}$ & 300 & 425 & 148,08 \\
\hline $\begin{array}{l}\text { Constanța-Poarta } \\
\text { Albă - Secția } \\
\text { exterioară Valu lui } \\
\text { Traian }\end{array}$ & 80 & - & - \\
\hline $\begin{array}{l}\text { Craiova } \\
\text { Secția exterioară } \\
\text { Işalnița }\end{array}$ & 80 & - & 88,10 \\
\hline Deva & 320 & - & 77,09 \\
\hline Focşani & 118 & 146 & 140,67 \\
\hline Găeşti & 192 & 20 & 104,71 \\
\hline Galați & 186 & 158 & 143,89 \\
\hline Gherla & 300 & 110 & 116,79 \\
\hline Giurgiu & 30 & - & 84,49 \\
\hline Iaşi & 600 & 464 & 166,38 \\
\hline Mioveni & 310 & - & 84,20 \\
\hline Pelendava & 325 & 75 & 135,71 \\
\hline $\begin{array}{l}\text { Ploieşti } \\
\text { Secția exterioară } \\
\text { Moara Nouă }\end{array}$ & 80 & - & - \\
\hline $\begin{array}{l}\text { Ploieşti } \\
\text { Secțiile exterioare } \\
\text { Movila Vulpii }\end{array}$ & 150 & 5 & 109,80 \\
\hline $\begin{array}{l}\text { Ploieşti } \\
\text { Târgşorul } \\
\text { Nou }\end{array}$ & 330 & 50 & 111,55 \\
\hline Târgu Jiu & 84 & 92 & 140,00 \\
\hline Târgu-Mureş & 210 & 92 & 147.92 \\
\hline $\begin{array}{l}\text { Timişoara } \\
\text { Secția exterioară } \\
\text { Buziaş }\end{array}$ & 300 & - & 86,25 \\
\hline Vaslui & 210 & 289 & 146,54 \\
\hline $\begin{array}{l}\text { Penitenciarul } \\
\text { P47 } \\
\text { Berceni }\end{array}$ & 1.000 & - & - \\
\hline
\end{tabular}

